\title{
Molecular cloning of partial 14-3-3 genes in the marine sponge Hymeniacidon perleve and its role in differentiating infectious and non-infectious bacteria
}

\author{
FU WanTao ${ }^{1,3,4}$, ZHANG JuLin ${ }^{1,5}$, ZHENG ChangBo ${ }^{6}$, LIU Jing ${ }^{1}$, AN ZhongFu ${ }^{1}$, \\ LIU HongWen ${ }^{7} \&$ ZHANG Wei ${ }^{2,3 *}$ \\ ${ }^{1}$ Institute of Marine Science-Technology and Environment, Dalian Ocean University, Dalian 116023, China; \\ ${ }^{2}$ Flinders Centre for Marine Bioproducts Development, and Department of Medical Biotechnology, School of Medicine, Flinders University, \\ Adelaide, SA 5042, Australia; \\ ${ }^{3}$ Marine Bioproducts Engineering Group, Dalian Institute of Chemical Physics, Chinese Academy of Sciences, Dalian 116023, China; \\ ${ }^{4}$ Key Laboratory of Nearshore Marine Environmental Science and Technology of Liaoning Higher Education, Dalian 116023, China; \\ ${ }^{5}$ Graduate School, Dalian Ocean University, Dalian 116023, China; \\ ${ }^{6}$ Vocation \& Technological College, Dalian Ocean University, Dalian 116000, China; \\ ${ }^{7}$ Dalian Environmental Monitoring Center, Dalian 116023, China
}

Received April 26, 2012; accepted June 21, 2012; published online September 1, 2012

\begin{abstract}
Sponges (phylum Porifera) are the phylogenetically oldest metazoa and highly efficient filter feeders. In the marine ecosystem, they are unconditionally exposed to environmental stresses. Understanding the sponge-bacteria interaction is hence of both ecological and biological significance. This study investigated the specific interaction between the sponge Hymeniacidon perleve and the non-infectious bacteria, Escherichia coli and infectious bacteria, Vibrio spp. by measuring the 14-3-3 mRNA expression of $H$. perleve. Three partial cDNAs of 14-3-3 proteins and partial 18S RNA in $H$. perleve were cloned and sequenced. Using Reverse-transcription real-time PCR, the 14-3-3 mRNA expression of $H$. perleve was examined when exposed to three common bacteria in aquatic water-E. coli and two Vibrio spp. for different time and dosages. H. perleve could efficiently remove $E$. coli from the water column without self-infection; however Vibrio at higher dosages infected $H$. perleve. When $H$. perleve was exposed to E. coli $\left(1.1 \times 10^{7} \mathrm{CFU} \mathrm{mL}{ }^{-1}\right)$, V. anguillarum II $\left(1.2 \times 10^{6} \mathrm{CFU} \mathrm{mL}^{-1}\right)$ and V. alginolyticus $\left(3.6 \times 10^{5} \mathrm{CFU} \mathrm{mL}^{-1}\right)$ for $6 \mathrm{~h}$, the 14-3-3 mRNA expression in the $V$. anguillarum II and $V$. alginolyticus groups was down-regulated by 2.67- and 2.36-fold, respectively. The 14-3-3 mRNA expression in the E. coli group was not significantly different. However, no clear trend was observed on the 14-3-3 transcript levels of $H$. perleve in response to different doses of $V$. anguillarum II for different time. The results demonstrated that infectious bacteria can be discriminated by 14-3-3 mRNA expression of sponge H. perleve.
\end{abstract}

marine sponge Hymeniacidon perleve, 14-3-3 mRNA, RT-PCR, infectious bacteria

Citation: $\quad$ Fu W T, Zhang J L, Zheng C B, et al. Molecular cloning of partial 14-3-3 genes in marine sponge Hymeniacidon perleve and its role in differentiating infectious and non-infectious bacteria. Chin Sci Bull, 2013, 58: 766-776, doi: 10.1007/s11434-012-5400-z

Sponges (Porifera) are the oldest metazoan phylum and still exist today $[1,2]$. As sessile filter feeders, sponges have the ability to filter large volumes of water $\left(0.002-0.84 \mathrm{~mL} \mathrm{~s}^{-1} \mathrm{~cm}^{-3}\right.$ of sponge tissue) through their aquiferous canal system to extract edible material [3-5], including bacteria, with about

*Corresponding author (email: wei.zhang@flinders.edu.au)
96\% retention efficiency [6]. Therefore, these animals are constantly exposed to many different microorganisms in seawater, such as bacteria [7] and viruses [8]. To face threats from different pathogenic bacteria in seawater, sponges have evolved with immune/defense mechanisms against these invaders over about 580 million years of their evolution [9]. Meanwhile sponges synthesize a huge number of bioactive 
secondary metabolites that show anti-bacterial activity [10-13]. Sponges are also reported to possess efficient humoral and cellular defense/immune mechanisms similar to those found in humans [14].

However, the precise relationship/interactions between sponge and microorganisms remain to be clarified for different types of microorganisms. Metchnikoff [15] firstly demonstrated that sponges eliminated bacteria by means of phagocytosis through their archeocytes. Wilkinson et al. [16] illustrated that marine sponges could discriminate between food bacteria and their bacterial symbionts. In the past 10 years, Perović-Ottstadt and colleagues [17] have done excellent work to document molecular responses to bacteria and fungi infection using the demosponges Suberites domuncula as the model system. For example, S. domuncula recognizes fungi through its receptor, the (1-3)- $\beta$-D-glucanbinding protein, on the cell surface. With respect to bacteria, the lectin of $S$. domuncula displays antibacterial activity against both Gram-negative and Gram-positive bacteria [18]. Thakur et al. [19] further reported that $S$. domuncula responded to Gram-positive bacteria with a rapid activation of endocytosis and increased synthesis of lysozyme. For Gram-negative bacteria, Bohm et al. [20] reported molecular biomarkers of sponge upon bacterial infection. p38 protein kinase and JNK protein kinase of the mitogen-activated protein kinase (MAPK) pathway were activated (phosphorylated) after the binding of lipopolysaccharide (LPS) to $S$. domuncula cells [20]. Wiens et al. [21] demonstrated that the receptor (LPS-interacting protein) on the surface of $S$. domuncula recognized Gram-negative bacteria and interacted with downstream molecules (MyD88 and macrophage-expressed protein). To the best of our knowledge, existing studies on sponges responding to bacterial infection used model inducer compounds, such as (1-3)- $\beta$-D-glucan, peptidoglycan (PPG) and LPS, rather than directly using live bacteria. Furthermore, whether sponges have the ability to differentiate between infectious and non-infectious bacteria and how this occurs, remain unknown. It would be fundamentally important because sponges do not have filtering selectivity of bacteria types.

The 14-3-3 protein is a family of $\sim 30 \mathrm{kD}$ highly conserved proteins within all eukaryotic cells [22]. This family of proteins, which includes 7 isotypes in human cells and up to 15 in plants [23], plays a critical role in many cellular processes such as signal transduction, cell-cycle control, apoptosis, viral and bacterial pathogenesis [24-26]. Through the specific phosphorylation interaction with its binding proteins, 14-3-3 proteins may respond to environment stresses at multiple levels [26,27], in particularly the defense response to viral and bacterial pathogen attack in plants [28-30]. In mammalian systems, 14-3-3 proteins block JNK and p38 activation (phosphorylation) [31,32]. Bohm et al. [20] found that the phosphorylation of the MAP kinase p38 and JNK in sponge $S$. domuncula was strongly increased after bacterial infection. In addition, Wiens et al. [33] reported that PCB 118 (2,3,4,4,5-pentachlorobiphenyl) induced the expression of 14-3-3 proteins in the marine sponge Geodia cydonium. Therefore, it may be logical to investigate if 14-3-3 proteins in sponges can be used as a biomarker to study the sponge-bacteria interaction.

The marine sponge, Hymeniacidon perleve, is a common intertidal demosponge species living on the rocky shores of Chinese Yellow Sea around Dalian, which was heavily polluted by microbial pathogen (Reports on Marine Pollution in China, 2006-2009). E. coli from human and animal waste pollute the coastal environment off the growing city of Dalian. In China, the concentrations of E. coli in seawater and some commercial bivalve products are more than that of allowable standard [34]. Fu et al. [34] has demonstrated that $E$. coli did not infect sponge and were retained efficiently by $H$. perleve. Chinese aquaculture products are approximately $70 \%$ of the world's products [35]. Vibrio spp. are common and major pathogens in Chinese marine aquaculture waters [34]. Fu et al. [34] also has demonstrated that $H$. perleve only can keep $V$. anguillarum II with lower initial concentration growth. To test the hypothesis that sponges may have the ability to differentiate between infectious and non-infectious bacteria by its molecular responses, we used $H$. perleve as a model sponge. In this study, we isolated and cloned three partial cDNDs of 14-3-3 proteins from $H$. perleve; used the 14-3-3 mRNA expression as the specific molecular biomarker to study the interactions between $H$. perleve and the two types of bacteria, E. coli as non-infectious bacteria, $V$. anguillarum II and $V$. alginolyticus as infectious bacteria.

\section{Materials and methods}

\subsection{Chemicals, bacterial strains and growth conditions}

All chemicals used were of analytical grade. LB medium, 2216E medium, bacteriological agar and TCBS agar were purchased and prepared as previously described [34]. Escherichia coli strain AS 1.1017 was obtained from Dalian Polytechnic University and was maintained in LB agar medium at $4^{\circ} \mathrm{C}$. Vibrio anguillarum II and Vibrio alginolyticus which were respectively obtained from Liaoning Institute of Aquaculture Science and Environment and Dalian Ocean University, were maintained in $2216 \mathrm{E}$ medium at $4^{\circ} \mathrm{C}$. Before tests, a $250-\mathrm{mL}$ flask containing $100 \mathrm{~mL} \mathrm{LB}$ medium was inoculated with a single colony of $E$. coli and placed on a rotary shaker at $200 \mathrm{r} \mathrm{min}^{-1}$ and $37^{\circ} \mathrm{C}$ for $17 \mathrm{~h}$. For $V$. anguillarum II and V. alginolyticus, all the culture conditions were the same as $E$. coli, except that $2216 \mathrm{E}$ medium and $28^{\circ} \mathrm{C}$ were used for the enrichment cultures.

\subsection{Sponge and seawater}

The marine sponge, Hymeniacidon perleve, was collected from the rocky shores of Chinese Yellow Sea around Dalian. 
The sampling, maintenance and acclimation of the sponge specimens before experiments were described previously [34]. The sterilized natural seawater (SNSW) was used and prepared as per [34].

\subsection{Interaction between sponge $H$. perleve and bacteria (E. coli, V. anguillarum II and V. alginolyticus)}

In the test of removal of E. coli and $V$. anguillarum II by $H$. perleve respectively, we adopted the experimental procedure of the previous study [34]. In the test of removal of $V$. alginolyticus by $H$. perleve, we only substituted $V$. anguillarum II with $V$. alginolyticus, otherwise the procedure was the same as previously [34].

In tests to validate if $E$. coli infects $H$. perleve, $500 \mu \mathrm{L} \mathrm{E}$. coli culture grown in LB medium for $17 \mathrm{~h}$ was added to 6 flasks containing $200 \mathrm{~mL}$ SNSW. Sponge clones of approximately $1.7 \mathrm{~g}$ were put into 5 flasks; one flask without sponge clones was used as the control. The 6 flasks were together placed on a rotary shaker at $100 \mathrm{r} \mathrm{min}^{-1}$ to keep water in constant movement. In $1.5 \mathrm{~h}$, one flask of treatment group and the control flask were taken away. Aliquots of seawater (100 $\mu \mathrm{L}$ ) were taken to dilute by 10 -fold and plated on the LB agar media in triplicate. The control group flask was placed back on the rotary shaker. Plates were incubated for $24 \mathrm{~h}$ at $37^{\circ} \mathrm{C}$ for CFU counting. Meanwhile the sponges in the flask which was taken away were taken to briefly wash twice by SNSW and homogenized with SNSW to obtain a final volume of 15 $\mathrm{mL}$. The number of $E$. coli in sponge clones was detected according to GB 17378.4-1998. In the same procedures, samples were taken and analyzed at 3, 6, 9 and $24 \mathrm{~h}$.

In the test of $V$. anguillarum II and $V$. alginolyticus infecting respectively $H$. perleve, $200 \mu \mathrm{L} \mathrm{V}$. anguillarum II cultures and $200 \mu \mathrm{L} \mathrm{V}$. alginolyticus cultures grown in $2216 \mathrm{E}$ medium for $17 \mathrm{~h}$ were respectively added to 6 flasks containing $200 \mathrm{~mL}$ SNSW. The other test conditions were the same as the tests on E. coli. To count $V$. anguillarum II and $V$. alginolyticus in SNSW, the seawater samples were 10 -fold diluted and plated on $2216 \mathrm{E}$ agar media in 3 replicates for $2 \mathrm{~d}$ at $28^{\circ} \mathrm{C}$. To count $V$. anguillarum II and $V$. alginolyticus in sponge clones, the sponge tissue was homogenized with SNSW to obtain a final volume of $15 \mathrm{~mL}$. The resultant solution was plated on TCBS media [34] in 3 replicates for $2 \mathrm{~d}$ at $28^{\circ} \mathrm{C}$ for counting colonies.

A sponge clone of $1.59 \mathrm{~g}$ was taken to be washed and homogenized with SNSW to also obtain a final volume of $15 \mathrm{~mL}$ to detect $E$. coli and Vibrio spp. concentration, which was regarded as the concentrations of E. coli and Vibrio spp. in sponge tissue at $0 \mathrm{~h}$. The analysis methods are the same as that described above.

\subsection{Extraction of Total RNA from $H$. perleve tissues and cells}

Total RNA which was used for cloning 14-3-3 mRNA of $H$. perleve was extracted from the dissociated mixed-cell population prepared with the protocol using TRIzol Reagent (Invitrogen) [36], according to [37]. Total RNA for all other studies was extracted from liquid nitrogen-pulverized sponge tissue samples with TRIzol Reagent (Invitrogen), also according to [37]. Total RNA was treated with RNase-free DNase I (TaKaRa) to remove DNA contamination according to the manufacturer's protocol. The concentration of RNA samples was determined on GeneQuant pro UV/Vis Spectrophotometer (Amersham Pharmacia Biotech). The quality and integrity of RNA samples was checked by agarose gel electrophoresis. The RNA was stored at $-80^{\circ} \mathrm{C}$.

\subsection{Cloning and sequencing three partial 14-3-3 mRNA from $H$. perleve}

The purified Total RNA derived from the dissociated mixed-cell population was reverse transcribed into cDNA on a Rotor-Gene 2000 Real Time Cycler (Corbett Research, Australia) at $30^{\circ} \mathrm{C}$ for $5 \mathrm{~min}$, then $42^{\circ} \mathrm{C}$ for $40 \mathrm{~min}$, finally RNase inactivation at $99^{\circ} \mathrm{C}$ for $5 \mathrm{~min}$. The reactor mixture included $1 \mu \mathrm{L} 10 \times \mathrm{RNA}$ PCR buffer, $2 \mu \mathrm{L} 25 \mathrm{mmol} \mathrm{L}^{-1}$ $\mathrm{MgCl}_{2}, 1 \mu \mathrm{L} 10 \mathrm{mmol} \mathrm{L}^{-1} \mathrm{dNTP}$ mixture, $0.5 \mu \mathrm{L}$ Oligo dT-Adaptor Primer (TaKaRa), $0.25 \mu \mathrm{L} 40 \mathrm{U} \mu \mathrm{L}^{-1}$ RNase inhibitor, $2 \mu \mathrm{L}$ Total RNA as template and $0.5 \mu \mathrm{L}$ 100-200 $\mathrm{U} \mu \mathrm{L}^{-1}$ AMV Reverse Transcriptase (TaKaRa), and then adjusted to $10 \mu \mathrm{L}$ with RNase Free $\mathrm{H}_{2} \mathrm{O}$. The cDNA was stored at $-20^{\circ} \mathrm{C}$.

The procedures for amplification of partial 14-3-3 cDNA of $H$. perleve were carried out using a Rotor-Gene 2000 Real Time Cycler (Corbett Research) at an initial denaturation at $94^{\circ} \mathrm{C}$ for $3 \mathrm{~min}$, followed by 35 amplification cycles at $94^{\circ} \mathrm{C}$ for $50 \mathrm{~s}, 54^{\circ} \mathrm{C}$ for $40 \mathrm{~s}$ and $72^{\circ} \mathrm{C}$ for $50 \mathrm{~s}$. The reaction mixture included $4 \mu \mathrm{L} 10 \times \mathrm{PCR}$ buffer, $3 \mu \mathrm{L} 25 \mathrm{mmol}$ $\mathrm{L}^{-1} \mathrm{MgCl}_{2}, 0.5 \mu \mathrm{L} 20 \mu \mathrm{mol} \mathrm{L} \mathrm{L}^{-1}$ Forward Primer and Reverse Primer respectively, $0.25 \mu \mathrm{L}$ LA Taq $\left(5 \mathrm{U}_{\mu} \mathrm{L}^{-1}\right)$ (TaKaRa) in $10 \mu \mathrm{L}$ reverse transcript reaction, then adjusted to $50 \mu \mathrm{L}$ with RNase free $\mathrm{H}_{2} \mathrm{O}$. Primers $\left(\mathrm{F}_{1} / \mathrm{R}_{1}\right)$ were designed against the highly conserved region (forward 5'-GTGTGGCCTACAAGAACGTG-3' against aa 50-56: SVAYKNV; reverse 5'-TGCATGATGAGAGTGGAGTC-3' against aa 218-224: DSTLIMQ) within the Demospongiae Geodia cydonium 14-3-3 (GenBank accession No. Y15900). The PCR samples were sent to TaKaRa Company to sequence.

For $3^{\prime}$-RACE, the poly $(\mathrm{A})^{+}$mRNA was reverse transcribed as described above, Oligo dT-Adaptor Primer in conjunction with the 3 '-end vector-specific primer M13M14. According to sequence results in this study, the forward primer $\left(\mathrm{F}_{2}\right)$ (5'-TCAGTAGCTTACAAGAATG-3') was designed against the highly conserved aa region (SVAYKNV), the reverse primer was M13M14 (5'-GTTTTCCCAGTCACGAC-3'). The PCR conditions were as described above, except annealing temperature at $42^{\circ} \mathrm{C}$ for $40 \mathrm{~s}$. PCR samples were also sent to TaKaRa Company to sequence. 


\subsection{Cloning and sequencing of partial 18S RNA from H. perleve}

The purified Total RNA was reverse transcribed on the GeneAmp PCR systems 2700 (Applied Biosystems) first at $30^{\circ} \mathrm{C}$ for $10 \mathrm{~min}$, then $42^{\circ} \mathrm{C}$ for $15 \mathrm{~min}$, finally RNase inactivation at $99^{\circ} \mathrm{C}$ for $5 \mathrm{~min}$. The reactor mixture, except 1 $\mu \mathrm{L}$ Total RNA as template and $0.5 \mu \mathrm{L}$ Random 9mers (50 $\mu \mathrm{mol} \mathrm{L} \mathrm{L}^{-1}$ ) representing Oligo dT-Adaptor Primer, was described above.

H. perleve partial 18S RNA was obtained by PCR. Primers $\left(\mathrm{F}_{3} / \mathrm{R}_{3}\right)$ were designed on the consensus conserved nucleotides region (forward primer 5'-TTGACGGAAGGGCACCA-3' and reverse primer 5'-CAAAGGGCAGGGACGTAATC-3') of 18S RNA in several sponge species (GenBank accession Nos. AJ620112, AJ627184, AY348885, AY737639). The PCR was performed on the GeneAmp PCR systems 2700 (Applied Biosystems) at an initial denaturation at $94^{\circ} \mathrm{C}$ for $2 \mathrm{~min}$, then 35 amplification cycles at $94^{\circ} \mathrm{C}$ for $30 \mathrm{~s}, 55^{\circ} \mathrm{C}$ for $30 \mathrm{~s}$ and $72^{\circ} \mathrm{C}$ for $60 \mathrm{~s}$. The reaction mixture included $10 \mu \mathrm{L} 5 \times$ PCR Buffer, $0.5 \mu \mathrm{L} 20 \mu \mathrm{mol} \mathrm{L}{ }^{-1}$ Forward Primer and Reverse Primer respectively, $0.25 \mu \mathrm{L}$

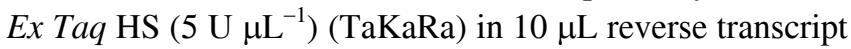
reaction, then adjusted to $50 \mu \mathrm{L}$ with RNase free $\mathrm{H}_{2} \mathrm{O}$. PCR sample were sent to TaKaRa Company to sequence.

\subsection{Sequence analysis}

The sequences were analyzed using BLAST (http://www. ncbi.nih.gov/blast). Multiple alignments were performed using Clustal X (1.8). Phylogenetic analysis was constructed on the basis of aa sequence aligments with Clustal X (1.8) and the TreeView software. A motif/pattern search was performed using PROSITE (http://www.Expasy.org/prosite/).

\subsection{Exposure of $H$. perleve to bacterial pathogens $(E$. coli, $V$. anguillarum II and $V$. alginolyticus)}

Vibrio spp. are common and major pathogens in Chinese marine aquaculture waters. In four $500 \mathrm{~mL}$ flasks, $500 \mu \mathrm{L} E$. coli culture, $200 \mu \mathrm{L}$ cultures of $V$. anguillarum II and $V$. alginolyticus each, were respectively added to 3 flasks containing $200 \mathrm{~mL} \mathrm{SNSW}$, one remaining flask without bacteria as control. The final concentration of E. coli, V. anguillarum II, and V. alginolyticus were approximately $1.1 \times 10^{7}$,

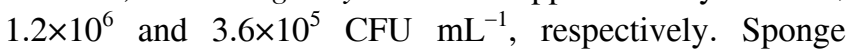
clones of approximate $1.5 \mathrm{~g}$ were separately put into four flasks. The 4 flasks were together placed on a rotary shaker at $100 \mathrm{r} \mathrm{min}^{-1}$ to keep water in constant movement. After $6 \mathrm{~h}$, aliquots of seawater $(100 \mu \mathrm{L})$ were taken from each flask for counting CFU [34]. Meanwhile the sponges were taken and placed respectively on 4 sterilized plates. Three small clones approximately $0.3 \mathrm{~g}$ were respectively cut from the 4 sponges for extracting Total RNA to detect 14-3-3 mRNA expression.

\subsection{Exposure of $\boldsymbol{H}$. perleve to $\mathrm{V}$. anguillarum $\mathrm{II}$ at different doses and times}

In the tests of exposure of $H$. perleve to $V$. anguillarum II with varying inoculum density (dose response) and varying time period (time course), the 14-3-3 mRNA expression of $H$. perleve was detected. In twelve 500-mL flasks containing $200 \mathrm{~mL} \mathrm{SNSW}$ each, the flasks in each groups, three flasks as one group, were respectively added 0, 5, 20 and $200 \mu \mathrm{L} \mathrm{V}$. anguillarum II cultures to obtain a density of 0 , $1.1 \times 10^{4}, 3.6 \times 10^{4}$ and $5.6 \times 10^{5} \mathrm{CFU} \mathrm{mL} \mathrm{m}^{-1}$. The group without bacteria addition was the control. The 12 flasks were respectively put into sponge clones about $1.5 \mathrm{~g}$ and then were together placed on a rotary shaker at $100 \mathrm{r} \mathrm{min}^{-1}$ to keep water in constant movement. In $1.5,3$ and $6 \mathrm{~h}$, one flask of each group was taken away. Aliquots of seawater $(100 \mu \mathrm{L})$ for the CFU counting and the sponge clones for total RNA extraction were sampled as above.

\subsection{Reverse transcript real-time PCR}

Partial 14-3-3 cDNA of $H$. perleve, containing 443 bp (GenBank accession No. DQ218450), was amplified by PCR on the GeneAmp PCR systems 2700 (Applied Biosystems) at an initial denaturation at $94^{\circ} \mathrm{C}$ for $3 \mathrm{~min}$, then 35 amplification cycles at $94^{\circ} \mathrm{C}$ for $50 \mathrm{~s}, 56^{\circ} \mathrm{C}$ for $35 \mathrm{~s}$ and $72^{\circ} \mathrm{C}$ for $40 \mathrm{~s}$, using reversed transcript mRNA as template (the condition was the same as above). The new primers $\left(\mathrm{F}_{4} / \mathrm{R}_{4}\right)$ were designed against the un-conserved region (forward, 5'-ATGCCAAGAGGTCATTGATC-3' against aa 64-70: ICQEVID; and reverse, 5'-CTTGCTCAGCGTCAACGTC-3' against aa 206-212: DVDAEQE) within $H$. perleve 14-3-3 (GenBank accession No. DQ218450). $H$. perleve partial $18 \mathrm{~S}$ ribosomal RNA of 451 bp (GenBank accession No. DQ206445) was amplified by PCR as describe above. The amplified partial 18S RNA and 14-3-3 cDNA were respectively T-A cloned into the expression plasmid pT7Blue (Novagen), and transfected to JM109 E. coli strain, selected on TB/Amp agar plates and verified by sequencing. The plasmids were used for in vitro transcription of the corresponding RNA by TaKaRa Company. After isolation and purification from the DNase RNase-free treated transcription solutions, the sense RNA transcripts were in vitro-transcribed. The RNA was quantitated accurately on GeneQuant Pro (Amersham Pharmacia Biotech) to construct standard curve for 14-3-3 mRNA as target gene and for 18S RNA as housekeeping gene.

Reverse transcription was then performed on the GeneAmp PCR systems 2700 (Applied Biosystems) as described above, $2 \mu \mathrm{L}$ total RNA as template and specific primer (5'-GTCAGCAGTCCACAAAGTCAGG-3') for 14-3-3 mRNA evaluation, $2 \mu \mathrm{L}$ of $10^{-3}$-diluted total RNA and specific primer (5'-CAATCCCCAGCACGACAA-3') for $18 \mathrm{~S}$ RNA. For Real time PCR, SYBR ${ }^{\circledR}$ RT-PCR Kit (Code: DRR041A) (TaKaRa) was used. Real time PCR was carried 
out using a Rotor-Gene 2000 Real Time Cycler (Corbett Research) at an initial denaturation at $94^{\circ} \mathrm{C}$ for $20 \mathrm{~s}$, then 35 amplification cycles at $94^{\circ} \mathrm{C}$ for $10 \mathrm{~s}$ and $60^{\circ} \mathrm{C}$ for $25 \mathrm{~s}$. The specific primers $\left(\mathrm{F}_{5} / \mathrm{R}_{5}\right)$ for 14-3-3 were designed (forward 5'-TGCATATACAGATGCCACTAG-3' against aa 123-129: SAYTDAT; reverse 5'-GTCAGCAGTCCACAAAGTCAGG-3' against aa 199-206: NLTLWTAD) within $H$. perleve 14-3-3 (GenBank accession No. DQ218450). The specific primers $\left(\mathrm{F}_{6} / \mathrm{R}_{6}\right)$ for $18 \mathrm{~S}$ RNA were designed (forward: 5'-AATTCCGATAACGAACGAGACC-3'; reverse: 5'-CAATCCCCAGCACGACAA-3') within $H$. perleve 18S RNA (GenBank accession No. DQ206445). The reaction mixture contained $12.5 \mu \mathrm{L} 2 \times$ Concentration SYBR Premix Ex Taq (including SYBR Green PCR Buffer, TaKaRa Ex Taq HS, dNTP Mixture, $\mathrm{Mg}^{2+}$, SYBR Green I) (TaKaRa), $0.5 \mu \mathrm{L} 10$ $\mu \mathrm{mol} \mathrm{L} \mathrm{L}^{-1}$ each primer for $14-3-3$ or for $18 \mathrm{~S}$ RNA, $2 \mu \mathrm{L}$ of reverse transcribed product as template, then adjusted to 25 $\mu \mathrm{L}$ with RNase free $\mathrm{H}_{2} \mathrm{O}$. The PCR reactions were carried out in duplicates.

A standard curve was respectively generated for each RT-PCR reaction (18S RNA and 14-3-3 mRNA) by known copy numbers (diluted to $10^{3}-10^{9}$ for $18 \mathrm{~S}$ RNA and $10^{4}-10^{9}$ copies for $14-3-3$ mRNA) of reverse transcribed product in vitro. Samples of unknown concentration were plotted onto the standard curve to calculate their concentration according to Operator's Manual on Rotor-Gene 2000 Real Time Cycler (Corbett Research). Reaction specificity for 18S RNA and 14-3-3 mRNA was respectively determined from the melt curve of the PCR product. All runs included a no template control, a no AMV reverse transcriptase control and a no primer control, and no PCR product was detected there.

\subsection{Nucleotide and amino acid sequence accession numbers}

The nucleotide sequence for $H$. perleve $18 \mathrm{~S}$ ribosomal RNA was deposited in GenBank (DQ206445). The amino acid sequences for $H$. perleve were designated as HP 14-3-3 A, HP 14-3-3 B and HP 14-3-3 H (GenBank accession Nos. DQ218448, DQ218449, DQ218450).

\subsection{Statistical analysis}

Triplicates were used in each treatment and the values throughout this article were presented as mean \pm standard deviation (SD). An independent Student's $t$-test was used to determine the statistical significance of differences.

\section{Results}

2.1 Interaction between bacteria ( $E$. coli, $V$. anguillarum II and $V$. alginolyticus) and sponge $H$. perleve

For the tests of removing E. coli, V. anguillarum II and $V$. alginolyticus in SNSW by $H$. perleve, the time courses of bacteria concentration are shown in Figure 1. The initial concentration of E. coli, V. anguillarum II and V. alginolyticus was $8.3 \times 10^{6}, 6.3 \times 10^{5}$ [34] and $3.9 \times 10^{5} \mathrm{CFU} \mathrm{\textrm {mL } ^ { - 1 }}$ (Figure 1), respectively.

During the tests, E. coli concentrations in the treatments declined markedly with time (Figure 1). At $9 \mathrm{~h}$, the average E. coli concentration was about $8.6 \%$ of the initial concentration. Accordingly, an average $9.13 \times 10^{7}$ bacterial cell $\mathrm{h}^{-1}$ $\mathrm{g}^{-1}$-fresh sponge was retained by the sponge [34]. The $E$. coli concentrations in the control flask have no significant difference with time $(P<0.02)$. Therefore $H$. perleve has an extremely high ability of removing $E$. coli in SNSW.

In the course of the tests, typical bacterial growth curves were observed in both the control and treatment cultures of $V$. anguillarum II and V. alginolyticus (Figure 1). At $10.5 \mathrm{~h}$, Vibrio spp. in the control was still in exponential phase, with

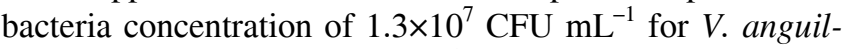
larum II and $1.1 \times 10^{7} \mathrm{CFU} \mathrm{mL}^{-1}$ for $V$. alginolyticus; however, Vibrio spp. in the treatment entered stationary phase at $9 \mathrm{~h}$, reaching $4.5 \times 10^{6} \mathrm{CFU} \mathrm{mL} \mathrm{m}^{-1}$ for $V$. anguillarum II and $4.6 \times 10^{6} \mathrm{CFU} \mathrm{mL} \mathrm{m}^{-1}$ for $V$. alginolyticus. It was clear that $H$. perleve, to some extent, has ability of controlling Vibrio spp. growth [34]. However, it is unknown how $H$. perleve interacts with bacteria (E. coli and Vibrio spp.) in seawater.

To validate whether bacteria have the ability of infecting $H$. perleve, sponge clones were respectively exposed to $E$. coli, V. anguillarum II and V. alginolyticus cultures for 1.5, 3, 6, 9 and 24 h. The time courses of E. coli, V. anguillarum II and $V$. alginolyticus concentration in SNSW and in sponge clones are shown in Table 1 . The weight of fresh sponge clones exposed to $E$. coli for $1.5,3,6,9$ and $24 \mathrm{~h}$ was $1.38,1.02,1.38,1.17$ and $1.32 \mathrm{~g}$, respectively. The weight of fresh sponge clones exposed to V. anguillarum II and $V$. alginolyticus was $1.85,1.91,2.37,2.26,1.93$ and $1.83,1.57,1.84,1.56,1.73 \mathrm{~g}$, respectively.

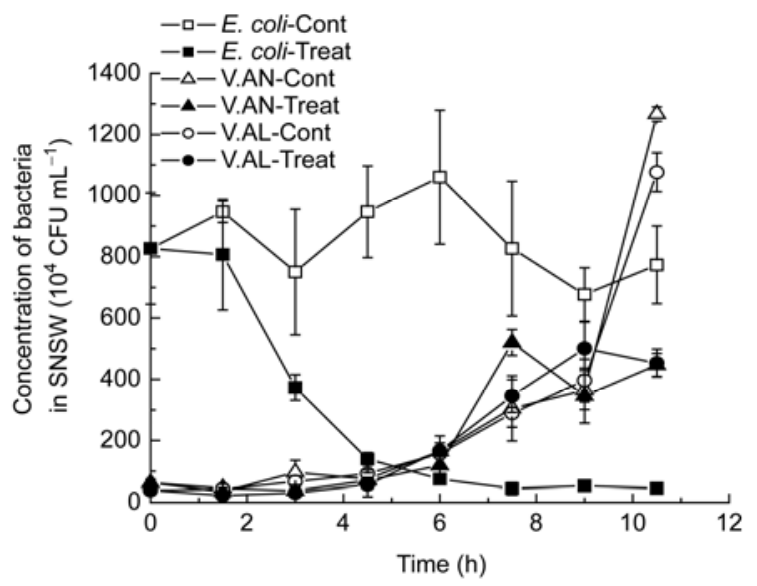

Figure 1 Removal kinetics of E. coli AS 1.1017 strain, V. anguillarum II and $V$. alginolyticus in sterile natural seawater (SNSW) supplemented with cultured E. coli, V. anguillarum II and V. alginolyticus over $10.5 \mathrm{~h}$. The error bars represent the standard deviation of three counting replicates. 
For the tests of $E$. coli infecting $H$. perleve, E. coli concentration in the control fluctuated among samples, but no significant change was observed $(P<0.05)$ (Table 1). E. coli concentrations in both SNSW and sponge clones in the treatments decreased markedly with time. These results demonstrated that $H$. perleve did not get infected by $E$. coli, but digested efficiently the E. coli retained from SNSW [34]. For the tests of $V$. anguillarum II and $V$. alginolyticus infecting $H$. perleve, the Vibrio spp. in the treatments quickly grew with time. This fitted in with the characteristics of Vibrio spp. In the treatment flasks, the concentration of Vibrio spp. in SNSW at 1.5 and $3 \mathrm{~h}$ was lower than initial concentration, respectively. The reason lies in the filtration of $H$. perleve. At 6 h, Vibrio spp. in SNSW in the treatments were respectively 3.1-fold for $V$. anguillarum II and 4.7-fold for $V$. alginolyticus higher than initial concentration, and increased over time. The concentrations of Vibrio spp. in sponge only at $1.5 \mathrm{~h}$ were slightly lower than initial concentration. From 3 h onward, Vibrio spp. in sponge increased markedly with time.

\subsection{Clone and sequence analysis of 18S RNA and 3 partial 14-3-3 cDNAs of $H$. perleve}

To obtain nucleotide sequences of partial 18S RNA and 143-3 mRNA from $H$. perleve, the total RNA purified was reverse transcribed and was amplified through PCR to sequence. A nucleotide sequence of $451 \mathrm{bp}$ was obtained for 18S RNA from $H$. perleve tissue using PCR amplification with specific primers $\left(\mathrm{F}_{3} / \mathrm{R}_{3}\right)$. The results from BLAST nucleotides sequence analysis show high similarity to other sponges: Halichondria melanodocia 18S RNA (AY 737639) (99\% identities), Suberites ficus (AJ 627184) (99\% identities), Suberites domuncula (AJ 620112) (99\% identities). The fragment was termed Hymeniacidon perleve $18 \mathrm{~S}$ ribosomal RNA (GenBank accession No. DQ206445).

Three partial sequences of 14-3-3 cDNA from the dissociated mixed-cell population of $H$. perleve were obtained using PCR amplification with primers $\left(\mathrm{F}_{1} / \mathrm{R}_{1}\right)$. Three fragments with 506, 518 and 583 bp, encoded partial sequences of three new 14-3-3 proteins from sponge $H$. perleve. According to three sequences obtained, the primer $\left(\mathrm{F}_{2}\right)$ was designed to amplify by PCR for 3'-RACE with the 3'-end vector-specific primer (M13M14). The three cDNA fragments was respectively comprised of 711 nucleotides, 749 nucleotides and 786 nucleotides, including the poly(A) tail. The deduced amino acids sequences (Figure 2), termed respectively HP 14-3-3 A, HP 4-3-3 B and HP 14-3-3 H (GenBank accession Nos. DQ218448, DQ218449, DQ218450 respectively), comprise 198 amino acids residues with a stop codon (TAA) at nucleotide position 592; 204 amino acids residues with a stop codon (TAA) at nucleotide position 610; and 219 amino acids residues with a stop codon (TAG) at nucleotide position 657. Through BLAST analysis, the three polypeptides HP 14-3-3 A, HP 14-3-3 B and HP 14-3-3 H, share respectively significant identity to G. cydonium 14-3-3 protein (CAA75860) of 56\%, 62\% and $61 \%$.

Further analysis of motif search reveals the presence of several motifs, patterns, and signatures in the three 14-3-3 polypeptides: Signature 1 in HP14-3-3 H, [RA]-N-L-[LIV]S-[VG]-[GA]-Y-[KN]-N-[IVA] (Prosite database PS000796) at the N-terminus; Signature 2 in all three 14-3-3 polypeptides, Y-K-[DE]-[SG]-T-L-I-[IML]-Q-L-[LF]-[RHC]-D-N[LF]-T-[LS]-W-[TANS]-[SAD](PS000797) at the C-terminus. The two regions, particular signature 2 as nuclear export signal (NES) motif, are highly conserved in all 14-3-3 protein family $[28,38]$.

A motif/pattern search (PROSITE) revealed protein kinase C phosphorylation sites ([ST]-x-[RK]; PS00005), Casein kinase II phosphorylation sites ([ST]-x(2)-[DE]; PS00006), a Tyrosine kinase phosphorylation site ([RK]$\mathrm{x}(2)-[\mathrm{DE}]-\mathrm{x}(3)-\mathrm{Y}$ or $[\mathrm{RK}]-\mathrm{x}(3)-[\mathrm{DE}]-\mathrm{x}(2)-\mathrm{Y}$; PS00007) in all three proteins; a cAMP- and cGMP-dependent protein kinase phosphorylation site ([RK]-(2)-X-[ST]; PS00004) in $H$. perleve-A and $H$. perleve-H; a cell attachment sequence (RGD; PS00016).

Table 1 Growth kinetics of bacteria (E. coli, V. anguillarum II and V. alginolyticus) in the seawater and the sponges when infecting sponge H. perleve

\begin{tabular}{|c|c|c|c|c|c|c|c|}
\hline \multirow{2}{*}{ Concentration of bacteria } & \multirow{2}{*}{ Exp group } & \multicolumn{6}{|c|}{ Sample time (h) } \\
\hline & & 0 & 1.5 & 3 & 6 & 9 & 24 \\
\hline \multirow{2}{*}{ E. coli in water $\left(10^{4} \mathrm{CFU} \mathrm{mL} \mathrm{m}^{-1}\right)$} & Cont & 827 & 947 & 750 & 1060 & 677 & 757 \\
\hline & Treat & 827 & 756 & 455 & 132 & 71 & 24 \\
\hline E. coli in sponge (cells $\mathrm{g}^{-1}$ ) & & 31.1 & 35.9 & 33.8 & 25.0 & 29.5 & 7.2 \\
\hline \multirow{2}{*}{ V. anguillarum $\mathrm{II}$ in water $\left(10^{4} \mathrm{CFU} \mathrm{mL}^{-1}\right)$} & Cont & 63 & 55 & 96 & 166 & 370 & 1069 \\
\hline & Treat & 63 & 39 & 36 & 196 & 448 & 1170 \\
\hline$V$. anguillarum $\mathrm{II}$ in sponge $\left(10^{4}\right.$ cells $\left.\mathrm{g}^{-1}\right)$ & & 12.3 & 8.1 & 39.3 & 82.3 & 159.3 & 352.3 \\
\hline \multirow{2}{*}{ V. alginolyticus in water $\left(10^{4} \mathrm{CFU} \mathrm{mL} \mathrm{m}^{-1}\right)$} & Cont & 39 & 43 & 66 & 157 & 396 & 1106 \\
\hline & Treat & 39 & 28 & 33 & 185 & 459 & 1249 \\
\hline$V$. alginolyticus in sponge $\left(10^{4}\right.$ cells $\left.\mathrm{g}^{-1}\right)$ & & 12.3 & 12.2 & 33.4 & 138.6 & 288.5 & 346.8 \\
\hline
\end{tabular}




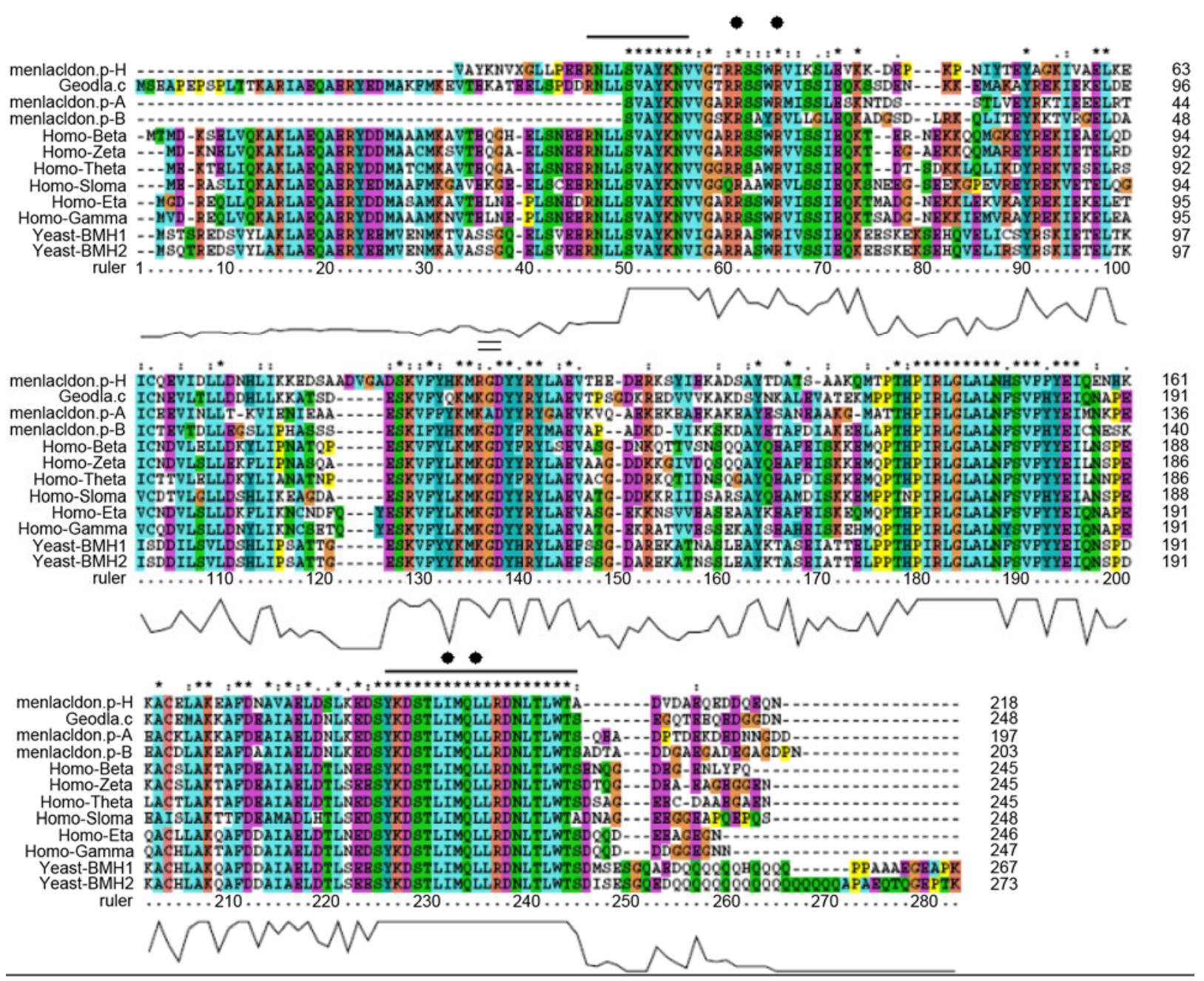

Figure 2 The deduced amino acid sequence from the Hymeniacidon perleve cDNA, termed respectively HP 14-3-3 A, HP 14-3-3 B and HP 14-3-3 H (GenBank accession Nos. DQ218448, DQ218449, DQ218450 respectively).

The three polypeptides were aligned with 6 isotypes of human cells and 2 isotypes of yeast (Figure 2). A rooted phylogenetic tree was constructed to show sequence relations of 14-3-3 polypeptides (Figure 3). The three polypeptides and the Demosponge G. cydonium 14-3-3 protein form the basis of the metazoan 14-3-3 proteins group, which share the highest sequence similarity with mammalians. Analysis of other polypeptides showed that sponge genes displayed predominantly the closest similarity/homology to corresponding human genes [39].

2.3 Discrimination of infectious bacteria (Vibrio spp.) and non-infectious bacteria $(E$. coli) by 14-3-3 mRNA differential expression in $H$. perleve

The 14-3-3 mRNA expression was investigated when sponge $H$. perleve was exposed to infectious bacteria (Vibrio spp.) and non-infectious bacteria (E. coli). 14-3-3 mRNA expression levels were normalized to the house-keeping gene $18 \mathrm{~S}$ RNA determined by RT-PCR. When $H$. perleve was exposed to E. coli $\left(1.0 \times 10^{7} \mathrm{CFU} \mathrm{mL}^{-1}\right), V$. anguillarum II $\left(1.2 \times 10^{6} \mathrm{CFU} \mathrm{mL}^{-1}\right)$ and $V$. alginolyticus $\left(3.6 \times 10^{5} \mathrm{CFU}\right.$ $\mathrm{mL}^{-1}$ ) for $6 \mathrm{~h}$, the 14-3-3 mRNA expression is shown in Figure 4. The 14-3-3 mRNA expression of $H$. perleve in the $E$. coli group was almost the same as that of the control group. The 14-3-3 mRNA expression in the $V$. anguillarum II and in the $V$. alginolyticus groups were down-regulated by 2.67- and 2.36-fold lower, respectively, when compared with the control group. However, the 14-3-3 mRNA expression level was not statistically different between the V.anguillarum II group and $V$. alginolyticus group $(P<0.05)$. The results show for the first time that differential expression in 14-3-3 mRNA was induced by infectious (Vibrio spp.) and non-infectious bacteria (E. coli).

\subsection{Dose and time-dependent responses of 14-3-3 mRNA expression of $H$. perleve to $V$. anguillarum II}

When $H$. perleve was exposed to $V$. anguillarum II at different concentrations and time periods, the 14-3-3 mRNA 


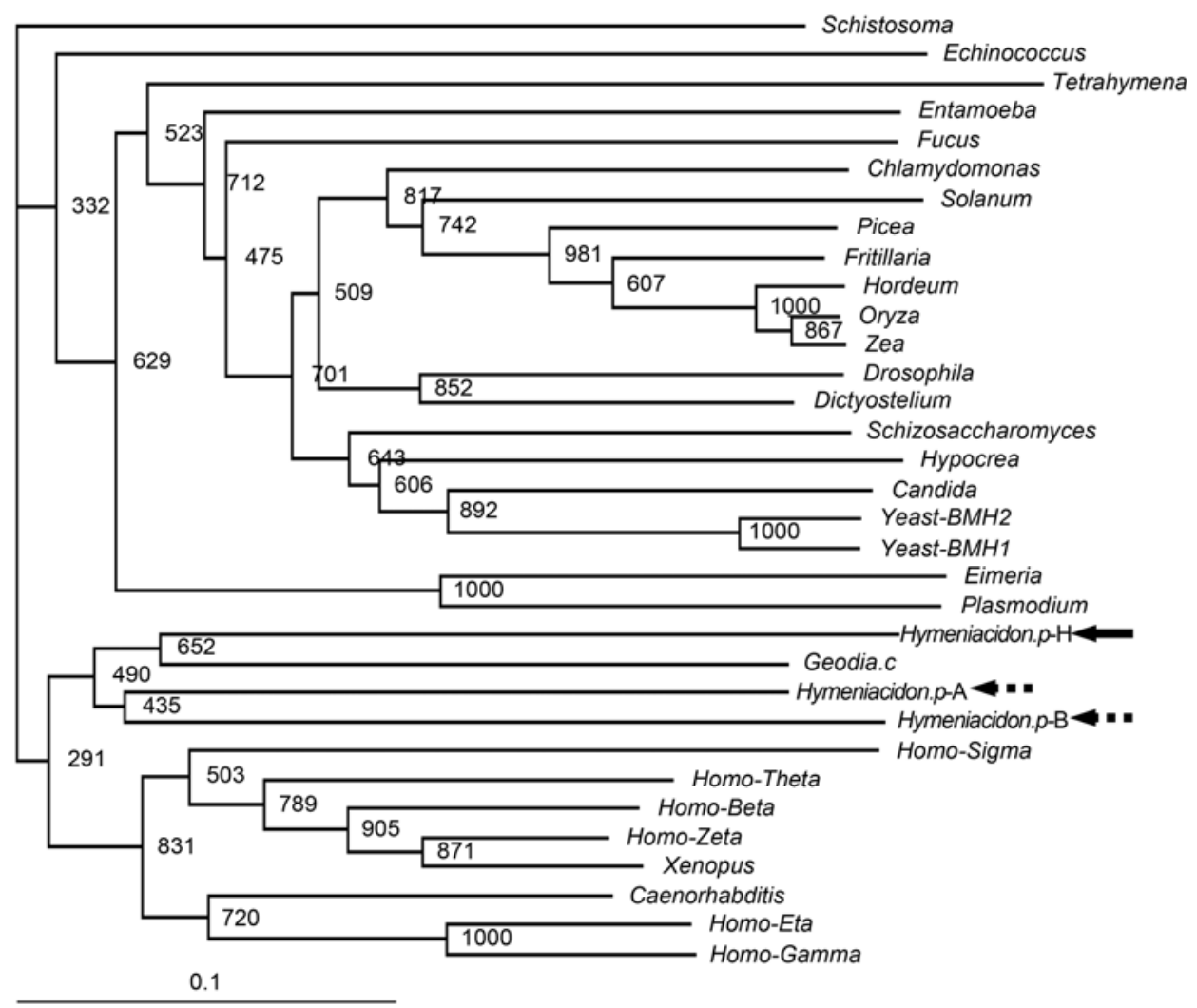

Figure 3 The rooted phylogenetic tree was constructed from the three sequences together with 14-3-3 protein from other organisms. (1) Sponge: Hymeniacidon.p-H(DQ218450), Hymeniacidon.p-A (DQ218448), Hymeniacidon.p-B (DQ218449), Geodia.c (CAA75860); (2) Human: Homo-Beta(2BQ0A), Homo-Eta (Q04917), Homo-Gamma (P61981), Homo-Sigma (AAC52030), Homo-Theta (P27348), Homo-Zeta (P63104); (3) Yeast: Yeast-BMH1 (P29311), Yeast-BMH2 (P34730); (4) Evolution: Caenorhabditis elegans (P41932), Candida albicans (O42766), Chlamydomonas reinhardtii (P52908), Dictyostelium discoideum (P54632), Drosophila melanogaster (P92177), Echinococcus multilocularis (AAC48315), Eimeria tenella (AAD02687), Entamoeba histolytica (P42649), Fritillaria (AAC04811), Fucus vesiculosus (Q39757), Hordeum vulgare (CAA74592), Hypocrea lixii (Q99002), Oryza sativa (AAB07456), Picea glauca (AAD27827), Plasmodium knowlesi (AAC17515), Schistosoma japonicum (AAD56715), Schizosaccharomyces (P42656), Solanum tuberosum (CAA72384), Tetrahymena pyriformis (BAA83080), Xenopus laevis (AAC41252), Zea mays (P49106).

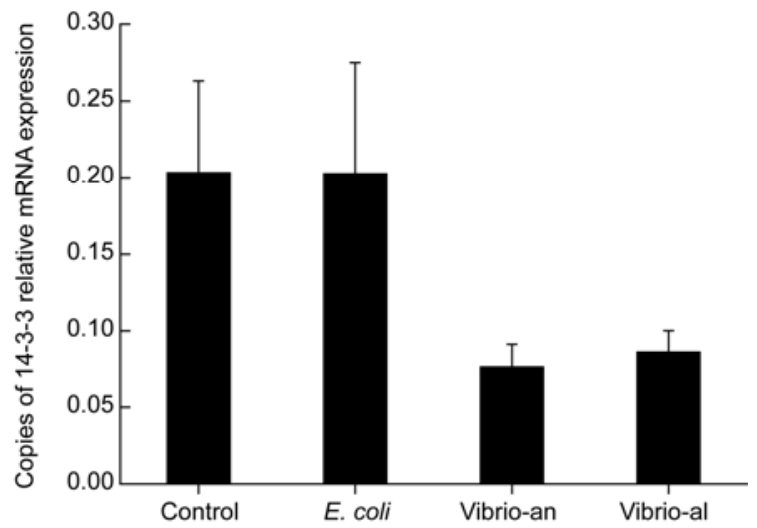

Figure 4 The 14-3-3 gene expression (mean $\pm \mathrm{SD})$ in H. perleve exposed

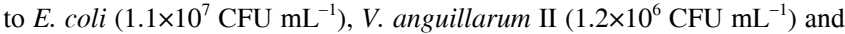
V. alginolyticus $\left(3.6 \times 10^{5} \mathrm{CFU} \mathrm{mL}^{-1}\right)$ for $6 \mathrm{~h}$, respectively.

expression level is shown in Figure 5. For the control group, the 14-3-3 mRNA expression at 1.5, 3 and $6 \mathrm{~h}$ was not significantly different $(P<0.05)$. In the test with $V$. anguillarum II at $1.1 \times 10^{4} \mathrm{CFU} \mathrm{mL}^{-1}$, the $14-3-3 \mathrm{mRNA}$ expression

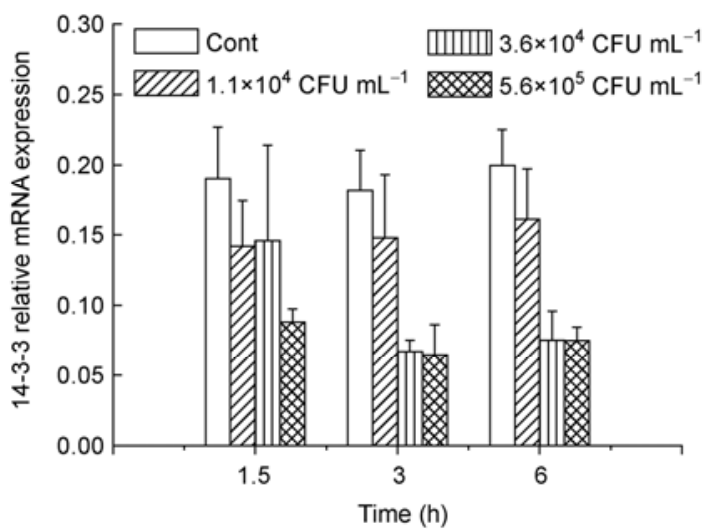

Figure 5 The 14-3-3 gene expression $(m e a n \pm S D)$ in $H$. perleve exposed to $V$. anguillarum $\mathrm{II}$ at $1.1 \times 10^{4} \mathrm{CFU} \mathrm{mL}^{-1}, 3.6 \times 10^{4} \mathrm{CFU} \mathrm{mL}^{-1}$ and $5.6 \times 10^{5}$ $\mathrm{CFU} \mathrm{mL} \mathrm{m}^{-1}$ for $1.5,3$ and $6 \mathrm{~h}$, respectively.

at $1.5,3$ and $6 \mathrm{~h}$ were not significantly different $(P<0.05)$, but slightly declined when compared with that of the control.

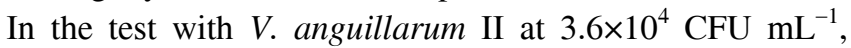
significant decrease in 14-3-3 mRNA expression level did 
not occur until $H$. perleve was exposed for $3 \mathrm{~h}$. The 14-3-3 mRNA expression level at 3 and $6 \mathrm{~h}$ was 2.71-fold and 2.65-fold lower than that of the control. In the test with $V$. anguillarum II at $5.6 \times 10^{5} \mathrm{CFU} \mathrm{mL}^{-1}$, the 14-3-3 gene expression level at $1.5,3$ and $6 \mathrm{~h}$ was respectively $2.16-, 2.82-$ and 2.66-fold lower than that of the control.

\section{Discussion}

In the recent two decades, outbreaks of diseases in wild and cultured marine organisms, due to microbial pathogens, have been frequent [40,41], particularly in China (Reports on Marine Pollution in China, 2001-2005). This has resulted in economic losses for the aquaculture industry [42]. As sessile filter feeders, sponges (phylum Porifera) are exposed to a large amount of microorganisms, including pathogenic bacteria. Besides their ability to remove microorganisms through phagocytosis [34] and characteristics to produce chemicals with anti-bacterial activity [13], sponges possess an efficient system of immune/defense mechanism [43]. In nearly a decade, the demosponge $S$. domuncula was used as the model system to study the molecular responses to bacteria [18-21] and fungi [17]. From 2002 to now, the marine sponge $H$. perleve maintains a healthy state in the field around Dalian City, but aquacultured sea cucumber and some bivalve molluscs, which are also filter feeders cultured in open seawater column in the same sea areas have suffered from infectious bacterial diseases. Through microbiology and molecular biology approaches, we have demonstrated for the first time that $H$. perleve could differentiate between infectious bacteria (Vibrio spp.) and non-infectious bacteria (E. coli) through molecular response (14-3-3 mRNA) to bacteria.

In the infection tests, E. coli as non-indigenous bacteria had been alive, but did not grow in seawater [34]. Hence, $E$. coli was used as the most common traced bacteria in the sponge filtering experiments $[44,45]$. Whereas the indigenous bacteria, Vibrio spp. reproduce rapidly in seawater [46] and are extremely infectious to aquacultured and wild animals, and humans [47]. Our results show that $H$. perleve has the ability to effectively retain $E$. coli in seawater, and the ability to control the growth of $V$. anguillarum II, to some degree. Here $H$. perleve exhibit a similar ability of controlling the growth of $V$. alginolyticus. Furthermore, the tests demonstrated that $E$. coli does not infect $H$. perleve. However, it was demostrated that both $V$. anguillarum II and $V$. alginolyticus have extremely high ability of infecting $H$. perleve (Table 1).

14-3-3 proteins are evolutionarily well conserved from yeast to human [38] and play critical roles in regulation of many cellular processes, such as signal transduction, cell cycle, and stress response [24,26,27,48]. Here we isolated three partial cDNA (including poly(A) tail) from the marine sponge $H$. perleve. The two signature regions of 14-3-3 proteins are highly conserved: signature 1 is a peptide of 11 residues located in the $\mathrm{N}$-terminal section; signature 2 , a 20 -amino acid region located in the $\mathrm{C}$-terminal section. The polypeptides of $H$. perleve-A and $H$. perleve-B do not include signature 1 , because of shorter amino acid sequences than that of $H$. perleve-H. In addition, most of the motifs found in the three 14-3-3 polypeptides are located at highly conserved residues (Figure 2). These findings support previously published results, that some highly conserved residues specifically bind to target proteins [49,50]. Nevertheless, there are different motifs among 14-3-3 isoforms of the same organism, such as a cell attachment sequence (RGD; PS00016) is only located at HP-H. This confirms that isoforms found in multicellular organisms have isoform-specific functions [38].

14-3-3 proteins have been examined as a biomarker for abiotic stress such as PCBs [33], however their expression patterns in response to biotic stress, such as bacterial infection, have not been studied. Using RT-PCR, the expression of 14-3-3 mRNA in $H$. perleve in response to live Gram-negative bacteria (E. coli and Vibrio spp.) was examined, rather than lipopolysaccharide (LPS) as a model inducing compound. The challenge of sponges with $E$. coli did not affect the 14-3-3 mRNA expression. When $H$. perleve was exposed to $V$. anguillarum II and V. alginolyticus, the 14-3-3 mRNA expression was down-regulated by 2.67- and 2.36-fold, respectively (Figures 4 and 5). Both $E$. coli and Vibrio spp. are Gram-negative bacteria with LPS, a major component of the outer membrane of Gram-negative bacteria [18], but 14-3-3 mRNA expression of $H$. perleve was different between the E. coli and the Vibrio spp. treatment. E. coli as non-indigenous bacteria did not grow in seawater and were rapidly digested by $H$. perleve [34]. Previous research has shown that $E$. coli is as a food source for sponge [6,44,51]. E. coli may only be phagocytosed by sponges and digested as food. In contrast, Vibrio spp. as indigenous marine bacteria, possess the ability to infect sponge (Figure 1 and Table 1). Our result for the first time demonstrated that infectious bacteria could be discriminated from non-infectious bacteria by the differential expression of 14-3-3 mRNA of the sponge $H$. perleve in response to bacteria.

However, these results may explain why the MAP kinases p38 and JNK in S. domuncula when exposed to LPS were strongly activated (phosphorylated) [20]. It was reported that 14-3-3 blocked p38 and JNK MAP activation (phosphorylation) in human [31] and in mice [32]. The 14-3-3 proteins [38] and Mitogen-activated protein kinases p38 and JNK [52] are evolutionarily well conserved from yeast to human. These 14-3-3 residues involved in binding p38 and JNK are $100 \%$ conserved in all eukaryotic organisms (Figure 2, [38]). The MAP kinases p38 and JNK are activated by phosphorylation at the dual phosphorylation TXY motif, which is highly conserved from yeast to human [53,54]. Hence the 14-3-3 proteins in sponges may have the ability 
of inhibiting phosphorylation of MAP kinases p38 and JNK. The present study showed that the expression of 14-3-3 mRNA of $H$. perleve was down-regulated during the exposure to the infectious bacteria Vibrio spp. As a result, the down-regulation of 14-3-3 mRNA expression led to the decrease in the ability of 14-3-3 blocking p38 and JNK activation (phosphorylation). In the future, the expression of each isoform of 14-3-3 proteins from $H$. perleve should be detected when exposed to pathogenic bacteria. As multi-gene analysis is available, the underlying mechanism of interaction of 14-3-3 proteins and their binding proteins which are also involved in pathogen-resistance response, such as p38 protein kinase and JNK protein kinase, should be investigated after the sponge is exposed to infectious bacteria.

\section{Conclusion}

Here we understand that the marine sponge $H$. perleve has the ability to discriminate between infectious bacteria from non-infectious bacteria through molecular response to different-type bacteria, and that both $V$. anguillarum II and $V$. alginolyticus have high ability of infecting sponge $H$. perleve. In the process of infecting the sponge $H$. perleve, Vibrio spp. also induce down-regulation of 14-3-3 mRNA of sponge $H$. perleve. $E$. coli is retained and then is fed on by $H$. perleve. The results from this study demonstrated that infectious bacteria can be discriminated by 14-3-3 gene expression of sponge $H$. perleve.

The authors thank financial supports from Chinese Academy of Sciences, "Innovation Fund" from Dalian Institute of Chemical Physics, National Hi-Tech Research and Development Program of China (2006AA09Z435), and the European Commission (Project: EVK3-CT1999-00005 UVTOX), Ph.D. Research Fund from Science and Technology Bureau of Liaoning Province of China (20091019), and Laboratory Program from Key Laboratory of Nearshore Marine Environmental Research of Liaoning Higher Education (LS2010024), and Science and Technology Program from Ocean and Fisheries Department of Liaoning Province of China (200917), Open Laboratory Program from Key and Open Laboratory of Marine and Estuarine Fisheries Resources and Ecology, Ministry of Agriculture of the People's Republic of China (Open-09-13) and Public Welfare Projects from State Oceanic Administration (200805030).

1 Müller W E G. Molecular phylogeny of Eumetazoa: Experimental evidence for monophyly of animals based on genes in sponges Porifera. Prog Mol Subcell Biol, 1998, 19: 89-132

2 Müller W E G. Origin of metazoa: Sponges as living fossils. Naturwissenschaften, 1998, 85: 11-25

3 Vogel S. Current-induced flow through living sponges in nature. Proc Natl Acad Sci USA, 1977, 74: 2069-2071

4 Rutzler K. New Perspectives in Sponge Biology. Washington D. C.: Smithsonian Institution Press, 1990. 504-515

5 Osinga R E H, Belarbi E M, Grima J, et al. Progress towards a controlled culture of the marine sponge Pseudosuberites andrewsi in a bioreactor. J Biotechnol, 2003, 100: 141-146

6 Simpson T L. The Cell Biology of Sponges. New York: Springer, 1984
7 Gonzales J M, Moran M A. Numerical dominance of a group of marine bacteria in the $\alpha$-subclass of the class Proteobacteria in coastal seawater. Appl Environ Microbiol, 1997, 63: 4237-4242

8 Bergh O, Borsheim K Y, Bratbak G, et al. High abundance of viruses found in aquatic environments. Nature, 1989, 340: 467-468

9 Li C W, Chen J Y, Hua T E. Precambrian sponges with cellular structures. Science, 1998, 279: 879-882

10 Proksch P. Defensive roles for secondary metabolites from marine sponges and sponge-feeding nudibranchs. Toxicon, 1994, 32: 639-655

11 Sarma A S, Daum T, Müller W E G. Secondary Metabolites from Marine Sponges. Berlin: Ullstein-Mosby Verlag, 1993

12 Kubanek J, Whalen K E, Engel S, et al. Multiple defensive roles for triterpene glycosides from two Caribbean sponges. Oecologia, 2002, 131: $125-136$

13 Müller W E G, Klemt M, Thakur N L, et al. Molecular/chemical ecology in sponges: Evidence for an adaptive antibacterial response in Suberites domuncula. Mar Biol, 2004, 144: 19-29

14 Müller W E G, Blumbach B, Müller I M. Evolution of the innate and adaptive immune systems: Relationships between potential immune molecules in the lowest metazoan Phylum (Porifera) and those in vertebrates. Transplantation, 1999, 68: 1215-1227

15 Metchnikoff E. Lecons sur la Pathologie Compare'e de Inflammation. Masson, Paris. 1892

16 Wilkinson C R, Garrone R, Vacelet J. Marine sponges discriminate food bacteria and bacterial symbionts: Electron microscope radioautography and in situ evidence. Proc Royal Soc B, 1984, 220: 519-528

17 Perović-Ottstadt S, Adell T, Proksch P, et al. A (1-3)- $\beta$-D-glucan recognition protein from the sponge Suberites domuncula. Mediated activation of fibrinogen-like protein and epidermal growth factor gene expression. Eur J Biochem, 2004, 271: 1924-1937

18 Schroder H C, Ushijima H, Krasko A, et al. Emergence and disappearance of an immune molecule, an antimicrobial lectin, in basal metazoa. A tachylectin-related protein in the sponge Suberites Domuncula. J Biol Chem, 2003, 278: 32810-32817

19 Thakur N L, Perovic-Ottstadt S, Batel R, et al. Innate immune defense of the sponge Suberites domuncula against gram-positive bacteria: Induction of lysozyme and adaPTin. Mar Biol, 2005, 146: 271282

20 Bohm M, Hentschel U, Friedrich A, et al. Molecular response of the sponge Suberites domuncula to bacterial infection. Mar Biol, 2001, 139: 1037-1045

21 Wiens M, Korzhev M, Krasko A, et al. Innate immune defense of the sponge Suberites domuncula against bacteria involves a MyD88dependent signaling pathway. J Biol Chem, 2005, 280: 27949-27959

22 Tzivion G, Gupta V S, Kaplun L, et al. 14-3-3 proteins as potential oncogenes. Sem Cancer Biol, 2006, 16: 203-213

23 Sehnke1 P C, Rosenquist M, Alsterfjord M, et al. Evolution and isoform specificity of plant 14-3-3 proteins. Plant Mol Biol, 2002, 50: 1011-1018

24 van Hemert M J, Yde S H, van Heusden G P H. 14-3-3 proteins: Key regulators of cell division, signaling and apoptosis. BioEssays, 2001, 23: 936-946

25 Yaffe M B. How do 14-3-3 proteins work? Gatekeeper phosphorylation and the molecular anvil hypothesis. FEBS Lett, 2002, 513: 53-57

26 Fu H, Subramanian R R, Masters S C. 14-3-3 proteins: Structure, function, and regulation. Ann Rev Pharmacol Toxicol, 2000, 40: 617-647

27 Roberts M R, Salinas J, Collinge D B. 14-3-3 proteins and the response to abiotic and biotic stress. Plant Mol Biol, 2002, 1031: 10311039

28 Lapointe G, Luckevich M D, Cloutier M, et al. 14-3-3 gene family in hybrid poplar and its involvement in tree defence against pathogens. $\mathrm{J}$ Exp Bot, 2001, 52: 1331-1338

29 Finnie C, Andersen C H, Borch J, et al. Do 14-3-3 proteins and plasma membrane $\mathrm{H}^{+}$ATPases interact in the barley epidermis in response to the barley powdery mildew fungus? Plant Mol Biol, 2002, 49: $137-147$

30 Roberts M R, Bowles D, Fusicoccin J. 14-3-3 proteins, and defense responses in tomato plants. Plant Physiol, 1999, 119: 1243-1250 
31 Xing H M, Zhang S S, Weinheimer C, et al. 14-3-3 proteins block apoptosis and differentially regulate MAPK cascades. EMBO J, 2000, 19: $349-358$

32 Gurusamy N, Watanabe K, Ma M L, et al. Dominant negative 14-3-3 promotes cardiomyocyte apoptosis in early stage of type I diabetes mellitus through activation of JNK. Biochem Biophys Res Commun, 2004, 320: 773-780

33 Wiens M, Koziol C, Hassanein H M A, et al. Induction of gene expression of the chaperones 14-3-3 and HSP70 by PCB 118 (2,3',4,4', 5-pentachloro-biphenyl) in the marine sponge Geodia cydonium: Novel biomarkers for polychlorinated biphenyls. Mar Ecol Prog Ser, 1998, 165: 247-257

34 Fu W T. Potential of Marine Sponge, Hymeniacidon perleve as bioremediator and bio-monitoring specie in integrated aquaculture ecosystem. Dissertation of Doctoral Degree. Dalian: Dalian Institute of Chemical Physics, Chinese Academy of Sciences, China, 2006

35 FAO, Fisheries Department. The State of World Fisheries and Aquaculture (SOFIA). Food and Agriculture Organization of the United Nations, 2004

36 Zhang X Y, Cao X P, Zhang W, et al. Primmorphs from archaeocytes-dominant cell population of the sponge Hymeniacidon perleve: Improved cell proliferation and spiculogenesis. Biotechnol Bioengin, 2003, 85: 1-8

37 Sambrook J, Russell D W. Molecular Cloning, a Laboratory Manual. 3rd ed. Cold Springs Harbor: Cold Springs Harbor Laboratory Press, 2001

38 Rosenquist M, Sehnke P, Ferl R J, et al. Evolution of the 14-3-3 protein family: does the large number of isoforms in multicellular organisms reflect functional specificity? J Mol Evol, 2000, 51: 446-458

39 Müller W E G, Müller I M. Origin of the metazoan immune system: Identification of the molecules and their functions in sponges. Integr Comp Biol, 2003, 43: 281-292

40 Walker P, Subasinghe R. DNA-based Molecular Diagnostic Techniques: Research Needs for Standardization and Validation of the Detection of Aquatic Animal Pathogens and Diseases. Report and Proceedings of the Expert Workshop on DNA-based Molecular Diagnostic Techniques: Research Needs for Standardization and Validation of the Detection of Aquatic Animal Pathogens and Diseases. Bangkok, Thailand, 7-9 February, 1999

41 Bower S M, McGladdery S E. Disease interactions between wild and cultured shellfish. A scientific review of the potential environmental effects of aquaculture in aquatic ecosystems, Volume 2. Fisheries and Oceans Canada. Can Tech Rep Fish Aquat Sci, 2003, 2450: viii + 33

42 Reilly A, Käferstein F. Food safety hazards and the application of the principles of the hazard analysis and critical control point (HACCP) system for their control in aquaculture production. Aquacult Res, 1997, 28: 735-752

43 Müller W E G, Müller I M. Analysis of the sponge (Porifera) gene repertoire: Implications for the evolution of the metazoan body plan. In: Müller W E G, ed. Marine Molecular Biotechnology, Sponges (Porifera). New York: Springer-Verlag Berlin Heidelberg, 2003

44 Reiswig H M. Bacteria as food for temperate-water marine sponges. Can J Zool, 1975, 53: 582-589

45 Frost $\mathrm{T}$ M. Selection in sponge feeding processes. In: Smith D C, Tiffon Y, eds. Nutrition in the Lower Metazoa. Oxford: Pergamon Press, 1980. 33-44

46 Xia Y J, Huang W Q, Huang B C, et al. Production and characterization of monoclonal anti-idiotype antibody to Vibrio anguillarum II. Fish Shellfish Immunol, 2002, 12: 273-281

47 Zampini M, Pruzzo C, Bondre V P, et al. Vibrio cholerae persistence in aquatic environments and colonization of intestinal cells: Involvement of a common adhesion mechanism. FEMS Microbiol Lett, 2005, 244: $267-273$

48 Ferl R J, Manak M S, Reyes M F. The 14-3-3s. Genome Biol, 2002, 3 $1-7$

49 Ichimura $\mathrm{T}$, Ito $\mathrm{M}$, Itakagi $\mathrm{C}$, et al. The 14-3-3 protein binds its target proteins with a common site located towards the C-terminus. FEBS Lett, 1997, 413: 273-276

50 Petosa C, Masters S C, Bankston L A, et al. 14-3-3Zeta binds a phosphorylated Raf peptide and an unphosphorylated peptide via its conserved amphipathic groove. J Biol Chem, 1998, 273: 1630516310

51 Osinga R, Tramper J, Wijffels R H. Cultivation of marine sponges. Mar Biotechnol, 1999, 1: 509-532

52 Widmann C, Gibson S, Jarpe M B, et al. Mitogen-activated protein kinases: Conservation of a three-kinase module from yeast to human. Physiol Rev, 1999, 79: 143-180

53 Wang X S, Diener K, Manthey C L, et al. Molecular cloning and characterization of a novel p38 mitogen-activated protein kinase. J Biol Chem, 1997, 272: 23668-23674

54 Kultz D. Phylogenetic and functional classification of mitogen- and stress-activated protein kinases. J Mol Evol, 1998, 46: 571-588

Open Access This article is distributed under the terms of the Creative Commons Attribution License which permits any use, distribution, and reproduction in any medium, provided the original author(s) and source are credited. 